\title{
PENENTUAN MODEL ANTREAN NON-POISSON DAN PENGUKURAN KINERJA PELAYANAN BUS RAPID TRANSIT TRANS SEMARANG (STUDI KASUS: SHELTER PEMBERANGKATAN BRT KORIDOR V)
}

\author{
Purwati Ayuningtyas $^{1 *}$, Sugito ${ }^{2}$, Di Asih I Maruddani ${ }^{3}$ \\ 1,2,3 Departemen Statistika, Fakultas Sains dan Matematika, Universitas Diponegoro \\ *e-mail : purwatiayu1211@gmail.com
}

\begin{abstract}
One of the queue systems that is often found in daily life is the transportation service system, for example a queue systemat the shelters departure of corridor VBus Rapid Transit (BRT) Trans Semarang. Corridor V has three departure shelters, they are Shelter Victoria Residence, Shelter Marina, and Shelter Bandara Ahmad Yani. Corridor V was choosen, because of its high load factor on January to June 2019. Based on the observation, the service time at the departure shelter is usually longer than the normal shelter. This cau ses the rise of queue at the departure shelters. The queue at the departure shelters can hamper the arrival of BRT at the other shelters, so the application of the queue theory is needed to find out the extent of operational effectiveness at the departure shelters. The resulting queue model is the Non-Poisson queue model, the queue

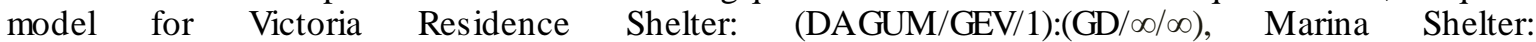

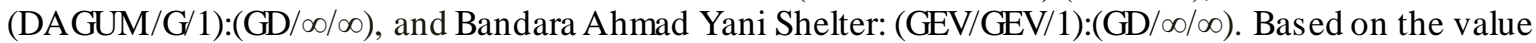
from measurement of the queue systemperformance, it can be conclude that the three departure shelters of corridor V BRT Trans Semarang have some optimal condition.
\end{abstract}

Keywords: Shelter Departure of Corridor V, Non-Poisson Queueing Model, Dagum, Generalized Extreme Value, System Perfomance Measure

\section{PENDAHULUAN}

Antrean, queuing atau waiting line, sangat sering dijumpai dalam kehidupan seharihari. Salah satu kelas sistem antrean yang dapat dijumpai yaitu sistem pelayanan transportasi. Beberapa dari sistem ini langganannya berupa kendaraan atau alat angkut. Fenomena sistem antrean tersebut salah satunya terlihat pada antrean shelter pemberangkatan BRT Trans Semarang. Saat ini BRT Trans Semarang menjadi transportasi umum pilihan masyarakat, karena harganya yang terjangkau dan dianggap lebih efektif. Menurut data BRT Trans Semarang, pada tahun 2019 rata-rata penumpang yaitu 33.000 dalam satu hari, rata-rata tersebut sangat meningkat dari tahun 2017 dengan rata-rata 21.000 penumpang dalam satu hari. Salah satu koridor yang memuat banyak penumpang yaitu koridor V, koridor ini menghubungkan rute Meteseh-Bandara Ahmad Yani-PRPP. Pada periode Januari-Juni 2019, load factor pada koridor V sebesar 93,18\%. Berdasarkan pengamatan yang telah dilakukan, waktu berhenti BRT pada shelter pemberangkatan biasanya lebih lama dibandingkan dengan shelter biasa. Hal tersebut menyebabkan adanya antrean pada shelter pemberangkatan. Adanya antrean pada shelter pemberangkatan dan kondisi kemacetan lalu lintas Kota Semarang dapat menghambat waktu kedatangan BRT pada shelter yang lain. Penerapan teori antrean sangat diperlukan untuk mengetahui efektifitas operasional pada shelter keberangkatan koridor V BRT Trans Semarang. Hasil analisis dapat dijadikan kajian untuk pengambilan keputusan pengembangan di shelter pemberangkatan koridor $\mathrm{V}$ yang efektif untuk masa mendatang. 


\section{TINJAUAN PUSTAKA}

\subsection{Profil Trans Semarang}

Trans Semarang merupakan sistem transportasi massal berbasis Bus Rapid Transit (BRT) terbesar di Jawa Tengah yang beroperasi di Kota dan Kabupaten Semarang. Kota Semarang yang termasuk kategori kota metropolitan merupakan salah satu latar belakang beroperasinya Trans Semarang. Selain itu, Pemerintah Kota Semarang melalui Dinas Perhubungan telah berhasil mengembangkan Bus Rapid Transit (BRT) sebagai program angkutan umum massal yang lebih nyaman, cepat, murah dan bersifat massal (Trans Semarang, 2018).

\subsection{Deskripsi Antrean}

Suatu proses antrean (queueing process) adalah suatu proses yang berhubungan dengan kedatangan seorang pelanggan pada suatu fasilitas pelayanan, kemudian menunggu dalam suatu baris (antrean) jika semua pelayannya sibuk, dan akhirnya meninggalkan fasilitas tersebut. Sebuah sistem antrean adalah suatu himpunan pelanggan, pelayan, dan suatu aturan yang mengatur kedatangan pelanggan dan pemrosesan masalahnya (Bronson dan Naadimuthu, 1997).

\subsection{Notasi Kendall}

Pada pengelompokan model antrean yang berbeda-beda digunakan suatu notasi yang disebut dengan Notasi Kendall. Notasi yang sering dipergunakan karena beberapa alasan. Diantaranya, karena notasi tersebut merupakan alat yang efisien untuk mengidentifikasi tidak hanya model-model antrean, tetapi juga asumsi-asumsi yang harus dipenuhi (Subagyo et al, 1992).

Menurut Kakiay (2004) bentuk kombinasi proses kedatangan dengan pelayanan pada umumnya dikenal sebagai standar universal, yaitu:

$$
(a / b / c):(d / e / f)
$$

di mana,

a : Distribusi kedatangan (arrival distribution).

$b \quad$ : Distribusi waktu pelayanan (service time distribution).

c : jumlah tempat pelayanan (dengan $c=1,2,3, \ldots \infty$ ).

$d \quad$ : disiplin pelayanan misalkan FIFO, LIFO, SIRO, SIP.

$e \quad$ : jumlah maksimum pelanggan yang diizinkan dalam sistem

$f \quad$ : sumber pemanggilan.

\subsection{Ukuran Steady-State}

Steady-state merupakan kondisi sewaktu sifat-sifat sistem tidak berubah dengan berjalannya waktu (konstan) (Kakiay, 2004). Menurut Taha (2017) misalnya $\lambda$ adalah rata-rata kedatangan pelanggan ke tempat pelayanan per satuan waktu, $\mu$ adalah rata-rata pelanggan yang telah dilayani per satuan waktu, dan $c$ merupakan banyaknya fasilitas pelayanan (server), maka $\rho$ didefinisikan sebagai perbandingan antara rata-rata pelanggan yang datang $(\lambda)$ dengan rata-rata pelanggan yang telah dilayani per satuan waktu $(\mu)$, atau dapat dituliskan sebagai berikut:

$$
\rho=\frac{\lambda}{c \mu}
$$


dengan $c$ merupakan jumlah fasilitas pelayanan yang tersedia. Saat kondisi steady-state, diharapkan bahwa rata-rata pelanggan yang datang memiliki nilai yang sebanding dengan rata-rata pelanggan yang telah dilayani atau dapat dikatakan rata-rata pelanggan yang datang tidak melebihi rata-rata pelanggan yang telah dilayani $(\lambda<c \mu)$, sehingga jika $\rho<1$ maka dapat diartikan memenuhi kondisi steady-state atau kondisi ketika sifat-sifat suatu sistem tak berubah dengan berjalannya waktu (konstan).

\subsection{Uji Kolmogorov-Smirnov}

Menurut Daniel (1989), uji kecocokan distribusi (goodness of fit) digunakan untuk menguji apakah sekumpulan data hasil pengamatan mengikuti distribusi tertentu. Uji ini didasarkan pada seberapa baik kecocokan antara frekuensi yang teramati dalam data sampel dengan frekuensi harapan yang didasarkan pada distribusi yang dihipotesiskan. Uji yang umum digunakan dalam uji goodness of fit adalah uji Kolmogorov-Smirnov.

Adapun langkah-langkah pengujian Kolmogorov-Smirnov adalah sebagai berikut:

a. Menentukan Hipotesis

$\mathrm{H}_{0}$ : Distribusi sampel mengikuti distribusi yang ditetapkan

$\mathrm{H}_{1}$ : Distribusi sampel tidak mengikuti distribusi yang ditetapkan

b. Menentukan Taraf Signifikansi

Taraf signifikasi yang digunakan adalah $\alpha$

c. Statistik Uji

$D=\operatorname{maximum}\left\{\operatorname{maximum}\left[\left|S\left(x_{i}\right)-F_{0}\left(x_{i}\right)\right| .\left|S\left(x_{i-1}\right)-F_{0}\left(x_{i}\right)\right|\right]\right\}$

dengan,

$S(x)$ : fungsi peluang kumulatif yang dihitung dari data sampel

$F_{0}(x)$ :fungsi distribusi yang dihipotesiskan (fungsi peluang kumulatif)

d. Kriteria Uji

Tolak $H_{0}$ pada taraf signifikansi $\alpha$, jika nilai $D>$ nilai $D_{\text {tabel }}(1-\alpha)$, atau jika nilai sig $<$ nilai $\alpha$. Dtabel $(\alpha)$ adalah nilai kritis yang diperoleh dari tabel Kolmogorov Smirnov.

\subsection{Dis tribusi Dagum}

Suatu peubah acak X dikatakan mempunyai distribusi Dagum dengan parameter $(a, b$, p) jika kepekatan peluang dari $\mathrm{X}$ adalah:

$$
f(x ; a, b, p)= \begin{cases}\frac{a p x^{a p-1}}{b^{a p}\left[1+\left(\frac{x}{b}\right)^{a}\right]^{p+1}} & ; x>0, a, b, p>0 \\ 0 \quad & \text { lainnya }\end{cases}
$$

dengan $(a, p)$ adalah parameter bentuk yang menunjukkan bentuk dari distribusi Dagum dan $\mathrm{b}$ adalah parameter skala yang menunjukkan besar keragaman dari distribusi Dagum (Kleiber dan Kotz, 2003). 


\subsection{Distribusi Generalized Extreme Value}

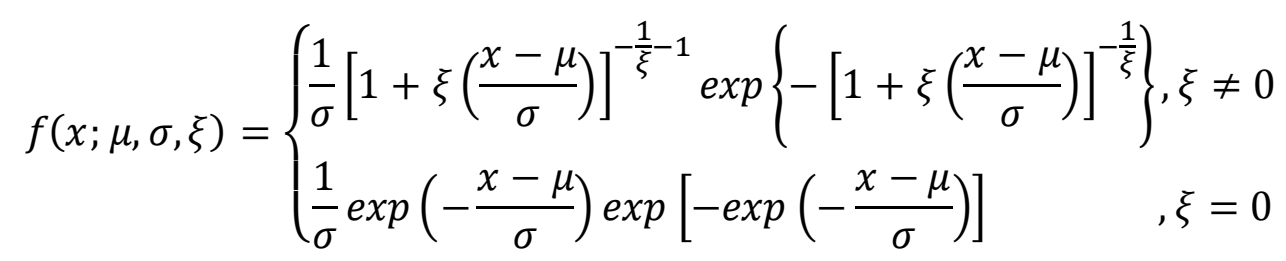

Menurut Kotz dan Nadarajah (2000) distribusi Generalized Extreme Value memiliki 3 parameter, yaitu:

a. $\sigma=$ parameter skala (scale)

b. $\mu=$ parameter lokasi (location)

c. $\xi=$ parameter bentuk (shape)

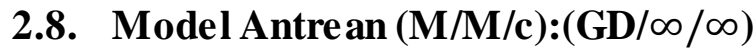

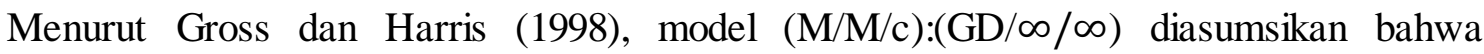
waktu pelayanannya berdistribusi Eksponensial dan waktu proses kedatangannya berdistribudi Poisson. Jika jumlah pelanggan dalam sistem adalah nsama dengan atau lebih besar dari c, maka laju keberangkatan gabungan dari sistem tersebut adalah $c \mu$. Jika $n$ lebih kecil dari $c$, maka laju pelayanannya adalah $n \mu$. Maka probabilitas untuk $n$ pelanggan dapat ditulis sebagai berikut:

$$
\begin{aligned}
& p_{n}= \begin{cases}\frac{\lambda^{n}}{n ! \mu^{n}} p_{0} & 1 \leq n \leq c \\
\frac{\lambda^{n}}{c^{n-c} c ! \mu^{n}} p_{0} & n \geq c\end{cases} \\
& p_{0}=\left(\sum_{n=0}^{c-1} \frac{r^{n}}{n !}+\frac{r^{c}}{c !(1-\rho)}\right)^{-1} \quad(\rho<1) \\
& \text { dengan } r=\lambda / \mu \text { dan } \rho=r / c=\lambda / c \mu .
\end{aligned}
$$

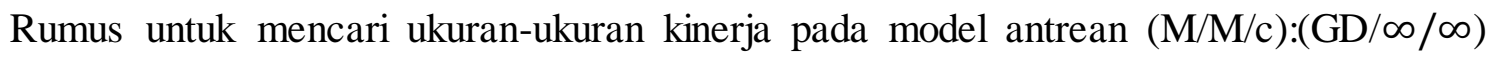
adalah sebagai berikut:

a. Jumlah pelanggan yang diperkirakan dalam antrean $\left(L_{q}\right)$

$$
L_{q}=\frac{r^{c} \rho}{c !(1-\rho)^{2}} p_{0}
$$

b. Jumlah pelanggan yang diperkirakan dalam sistem $\left(L_{S}\right)$

$$
L_{s}=L_{q}+r
$$

c. Waktu menunggu yang diperkirakan dalam sistem $\left(W_{S}\right)$

$$
W_{s}=W_{q}+\frac{1}{\mu}
$$

d. Waktu menunggu yang diperkirakan dalam antrean $\left(W_{q}\right)$

$$
W_{q}=\frac{L_{q}}{\lambda}
$$

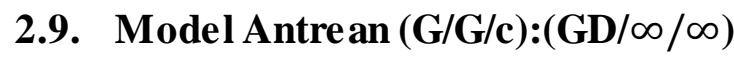

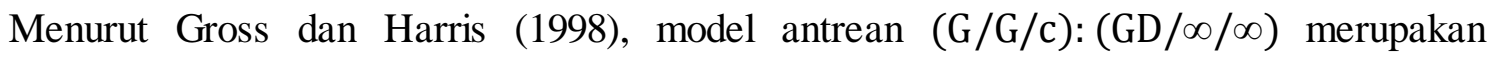
model antrean dengan pola kedatangan beristribusi umum (general) dan pola pelayanan berdistribusi umum (general), dengan jumlah fasilitas pelayanan sebanyak $c, c=1,2,3, \ldots$. 
Disiplin antrean yang digunakan pada model ini adalah umum yaitu FIFO (First in First Out), kapasitas maksimum yang diperbolehkan dalam sistem beserta sumber pemanggilannya tak terbatas.

Ukuran kinerja sistem pada model general ini mengikuti ukuran kinerja pada model $M / M / C$, terkecuali untuk perhitungan jumlah pelanggan yang diperkirakan dalam antrean $\left(L_{q}\right)$. Rumus untuk mencari jumlah pelanggan yang diperkirakan dalam antrean $\left(L_{q}\right)$ pada model $(G / G / c):(G D / \infty / \infty)$ adalah sebagai berikut:

$$
\begin{aligned}
& L_{q M / M / c}=\frac{r^{c} \rho}{c !(1-\rho)^{2}} p_{0} \\
& L_{q}=L_{q M / M / c} \frac{\mu^{2} v(t)+v\left(t^{\prime}\right) \lambda^{2}}{2} \\
& \text { di mana, } \\
& v(t): \text { varian dari waktu pelayanan }\left(\frac{1}{\mu^{2}}\right)^{2} \\
& v\left(t^{\prime}\right): \text { varian dari waktu antar kedatangan }\left(\frac{1}{\lambda^{2}}\right)^{2}
\end{aligned}
$$

\section{METODOLOGI PENELITIAN}

\subsection{Jenis dan Sumber Data}

Data yang digunakan adalah data primer yaitu data yang diperoleh dengan pengamatan dan pencatatan langsung dari obyek penelitian. Penelitian dilakukan dengan mengambil sampel data selama 7 hari untuk masing-masing shelter pemberangkatan. Sampel tersebut dianggap telah mewakili hari kerja dan akhir pekan. Diasumsikan bahwa pola kedatangan dan pola keberangkatan pelanggan dilayani pada shelter pemberangkatan koridor V BRT Trans Semarang tidak berubah, sehingga dapat mewakili populasi hari lainnya.

\subsection{Tempat dan Waktu Penelitian}

Penelitian dilaksanakan di shelter pemberangkatan BRT Trans Semarang koridor V, yaitu Shelter Bandara pada tanggal 21-27 Desember 2019, Shelter Victoria Residence pada tanggal 23-29 Desember 2019, dan Shelter Marina pada tanggal 4-10 Januari 2020. Penelitian dilakukan mulai pukul 05.00 sampai dengan pukul 18.00 WIB setiap harinya untuk Shelter Victoria Residence dan Shelter Marina. Untuk Shelter Bandara Ahmad Yani dilakukan pada pukul 17.00 sampai dengan pukul 23.00 WIB.

\subsection{Variabel Penelitian}

Variabel yang digunakan dalam penelitian ini adalah:

a. Data jumlah BRT yang datang dan jumlah BRT yang terlayani pada shelter pemberangkatan koridor $\mathrm{V}$.

b. Data waktu antar kedatangan dan waktu pelayanan BRT pada shelter pemberangkatan koridor V

\subsection{Alat Analis is}

Alat yang digunakan untuk melakukan pencatatan waktu kedatangan kendaraan dan lamanya waktu pelayanan adalah digital clock. Sementara output yang dihasilkan merupakan hasil pengolahan data menggunakan software statistika, yaitu Rstudio (GUI R), Easy Fit Profesional, dan Microsoft Excel. 


\subsection{Langkah-Langkah Penelitian}

1. Menentukan tempat penelitian dan metode yang akan digunakan.

2. Melakukan penelitian secara langsung di shelter pemberangkatan koridor V BRT Trans Semarang, untuk mendapatkan data jumlah kedatangan, data banyaknya pelayanan, data waktu antar kedatangan dan data waktu pelayanan dalam satuan waktu yang telah ditetapkan.

3. Data yang diperoleh harus memenuhi kondisi steady-state.

4. Melakukan uji kecocokan distribusi untuk kedatangan dan pengunjung terlayani dengan menggunakan uji Kolmogorov-Smirnov.

5. Menentukan model antrean yang sesuai.

6. Menentukan ukuran kinerja sistem.

7. Membuat hasil dan pembahasan yang diperoleh dari ukuran kinerja sistem.

8. Mengambil kesimpulan mengenai pelayanan di shelter pemberangkatan koridor V BRT Trans Semarang secara keseluruhan.

\section{HASIL DAN PEMBAHASAN}

Koridor V BRT Trans Semarang merupakan koridor yang menghubungkan MetesehBandara Ahmad Yani-PRPP. Koridor V memiliki tiga shelter pemberangkatan, yaitu Shelter Victoria Residence, Shelter Marina dan Shelter Bandara Ahmad Yani. Sistem antrean BRT di Shelter Pemberangkatan Koridor V adalah sebagai berikut:

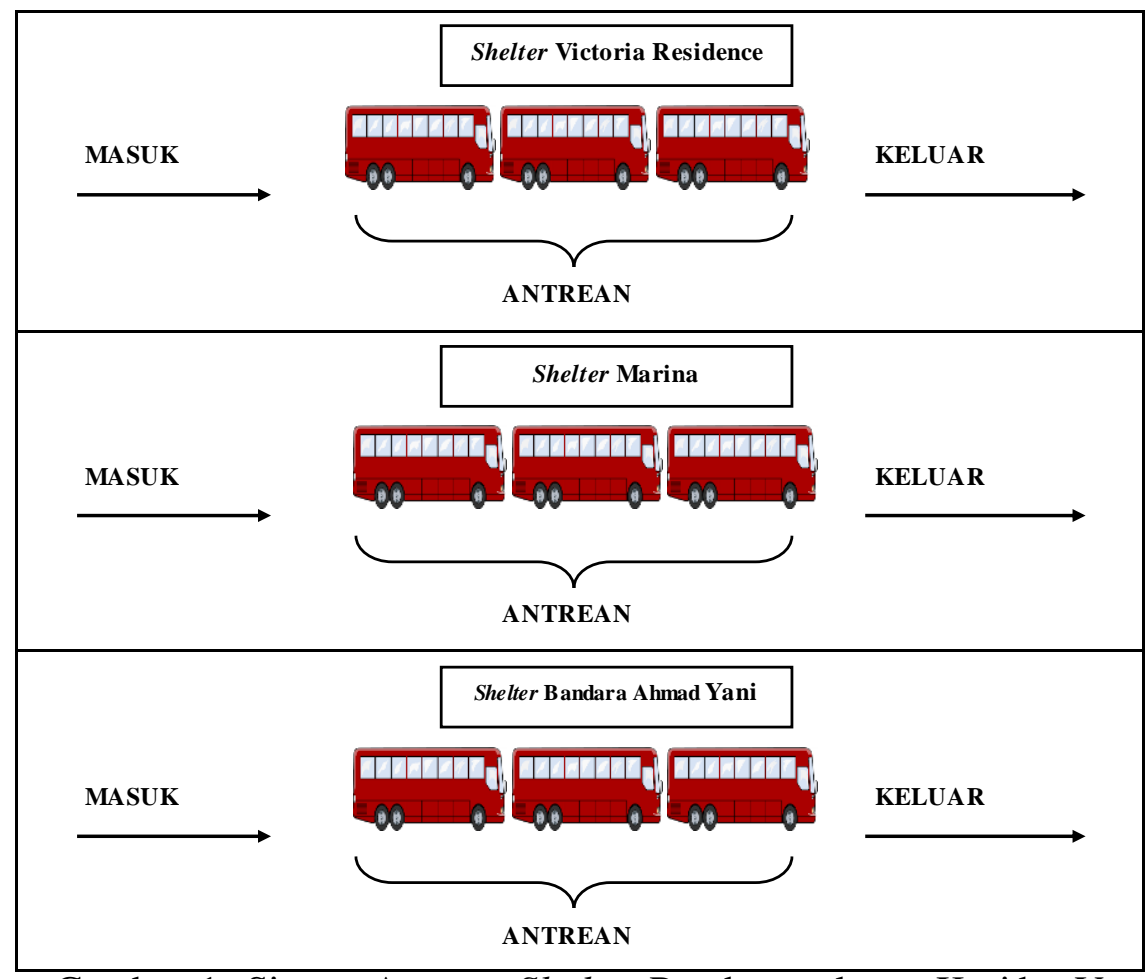

Gambar 1. Sistem Antrean Shelter Pemberangkatan Koridor V

\subsection{Analisis Steady-State}

Kondisi steady-state terpenuhi jika nilai tingkat kegunaan $(\rho)<1$ artinya rata-rata laju kedatangan BRT di jalur tersebut lebih kecil dari rata-rata laju pelayanan. Kondisi steadystate harus terpenuhi sehingga dapat diketahui bahwa jumlah rata-rata pelanggan yang datang 
lebih kecil dari rata-rata laju pelayanan agar sistem pelayanan mencapai keadaan yang stabil. Berikut hasil perhitungan nilai $\rho$ :

Tabel 1. Analisis Steady-State

\begin{tabular}{lcccc}
\hline \multicolumn{1}{c}{ Shelter } & $\boldsymbol{c}$ & $\boldsymbol{\lambda}$ & $\boldsymbol{\mu}$ & $\boldsymbol{\rho}=\boldsymbol{\lambda} /(\boldsymbol{c \mu})$ \\
\hline Victoria Residence & 1 & 5,26049 & 7,76912 & 0,67710 \\
Marina & 1 & 5,11444 & 11,90207 & 0,42971 \\
Bandara Ahmad Yani & 1 & 3,57261 & 4,38436 & 0,81485 \\
\hline
\end{tabular}

dari Tabel 1 dapat diketahui bahwa nilai tingkat kegunaan fasilitas pelayanan $(\rho)$ ketiga shelter pemberangkatan kurang dari satu. Sehingga dapat disimpulkan bahwa sistem antrean ketiga shelter pemberangkatan tersebut sudah steady-state, yaitu rata-rata tingkat kedatangan BRT tidak melebihi rata-rata tingkat pelayanan.

\subsection{Uji Distribusi}

Uji kecocokan distribusi yang digunakan untuk menguji data waktu antar kedatangan dan waktu pelayanan BRT pada shelter pemberangkatan koridor V. Pada uji tersebut akan diketahui apakah data waktu antar kedatangan dan waktu pelayanan BRT pada masingmasing shelter pemberangkatan berdistribusi Eksponensial atau tidak.

\subsubsection{Uji Distribusi Data Waktu Antar Kedatangan}

Berikut ini adalah hasil uji distribusi dari data waktu antar kedatangan BRT setiap 60 menit untuk ketiga shelter pemberangkatan koridor $\mathrm{V}$ :

Tabel 2. Uji Distribusi Data Waktu Antar Kedatangan

\begin{tabular}{|c|c|c|c|c|c|}
\hline Shelter & Dhitung & $D_{\text {tabel }}$ & $p$-value & Keputusan & Kesimpulan \\
\hline Victoria Residence & 0,10256 & 0,06467 & 0,000187 & $\mathrm{H}_{0}$ ditolak & $\begin{array}{l}\text { Tidak berdistribusi } \\
\text { Eksponensial }\end{array}$ \\
\hline Marina & 0,07297 & 0,06409 & 0,01678 & $\mathrm{H}_{0}$ ditolak & $\begin{array}{l}\text { Tidak berdistribusi } \\
\text { Eksponensial }\end{array}$ \\
\hline Bandara Ahmad Yani & 0,15693 & 0,11776 & 0,00286 & $\mathrm{H}_{0}$ ditolak & $\begin{array}{l}\text { Tidak berdistribusi } \\
\text { Eksponensial }\end{array}$ \\
\hline
\end{tabular}

Jadi, pada taraf signifikansi 5\% didapatkan hasil bahwa data waktu antar kedatangan BRT pada Shelter Victoria Residence, Shelter Marina, dan Shelter Bandara Ahmad Yani tidak berdistribusi Eksponensial. Sehingga dapat disimpulkan data waktu antar kedatangan BRT pada ketiga shelter pemberangkatan koridor V BRT Trans Semarang berdistribusi General.

\subsubsection{Uji Distribusi Data Waktu Pelayanan}

Berikut ini adalah hasil uji distribusi dari data waktu pelayanan BRT setiap 60 menit untuk ketiga shelter pemberangkatan koridor V:

Tabel 3. Uji Distribusi Data Waktu Pelayanan 


\begin{tabular}{lcccll}
\hline \multicolumn{1}{c}{ Shelter } & D $_{\text {hitung }}$ & D $_{\text {tabel }}$ & p-value & Keputusan & \multicolumn{1}{c}{ Kesimpulan } \\
\hline Victoria Residence & 0,26436 & 0,06416 & $2,2 \mathrm{e}-16$ & $\mathrm{H}_{0}$ ditolak & Tidak berdistribusi \\
Marina & 0,12545 & 0,06360 & $1,169 \mathrm{e}-06$ & $\mathrm{H}_{0}$ ditolak & $\begin{array}{l}\text { Eksponensial } \\
\text { Tidak berdistribusi } \\
\text { Bandara Ahmad Yani }\end{array}$ \\
& 0,2955 & 0,11478 & $4,814 \mathrm{e}-11$ & $\mathrm{H}_{0}$ ditolak & $\begin{array}{l}\text { Eksponensial } \\
\text { Tidak berdistribusi } \\
\text { Eksponensial }\end{array}$ \\
\hline
\end{tabular}

Jadi, pada taraf signifikansi 5\% didapatkan hasil bahwa data waktu pelayanan BRT pada Shelter Victoria Residence, Shelter Marina, dan Shelter Bandara Ahmad Yani tidak berdistribusi Eksponensial. Sehingga dapat disimpulkan data waktu pelayanan BRT pada ketiga shelter pemberangkatan koridor V BRT Trans Semarang berdistribusi General.

\subsection{Model Sistem Antrean}

Berdasarkan hasil analisis steady-state serta uji kecocokan distribusi waktu antar kedatangan dan waktu pelayanan BRT Trans Semarang dapat ditentukan bahwa model sistem antrean untuk Shelter Victoria Residence, Shelter Marina, dan Shelter Bandara Ahmad Yani

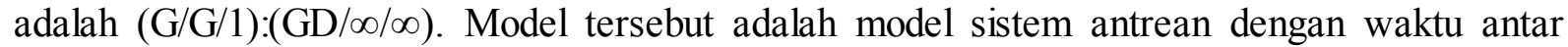
kedatangan berdistribusi umum (General) dan waktu pelayanan berdistribusi umum (General), dengan jumlah sistem pelayanan sebanyak satu shelter, disiplin antrean yang digunakan adalah yang pertama datang yang pertama dilayani (FIFO), serta jumlah kapasitas pelanggan yang datang dan sumber pemanggilan tak terbatas.

Untuk mengetahui distribusi yang sebenarnya dari waktu antar kedatangan dan waktu pelayanan ketiga shelter pemberangkatan koridor $\mathrm{V}$ yang berdistribusi General maka dilakukan pengujian distribusi berdasarkan output Easy Fit. Berikut adalah hasil uji kecocokan distribusi waktu antar kedatangan dan waktu pelayanan shelter Bandara menggunakan uji Kolmogorov- Smirnov.

Tabel 4. Uji Distribusi Hasil Easy Fit Data Waktu Antar Kedatangan

\begin{tabular}{lccccl}
\hline \multicolumn{1}{c}{ Shelter } & D $_{\text {hitung }}$ & $\mathbf{D}_{\text {tabel }}$ & $\boldsymbol{p}$-value & Keputusan & \multicolumn{1}{c}{ Kesimpulan } \\
\hline Victoria Residence & 0,04036 & 0,06467 & 0,45715 & $\mathrm{H}_{0}$ diterima & Berdistribusi Dagum \\
Marina & 0,02234 & 0,06409 & 0,9749 & $\mathrm{H}_{0}$ diterima & Berdistribusi Dagum \\
Bandara Ahmad Yani & 0,08157 & 0,11775 & 0,32145 & $\mathrm{H}_{0}$ diterima & $\begin{array}{l}\text { Berdistribusi Generalized } \\
\text { Extreme Value }\end{array}$ \\
\hline
\end{tabular}

Jadi, pada taraf signifikansi 5\% didapatkan hasil bahwa data waktu antar kedatangan BRT pada Shelter Victoria Residence dan Shelter Marina berdistribusi Dagum. Sedangkan Shelter Bandara Ahmad Yani berdistribusi Generalized Extreme Value.

Tabel 5. Uji Distribusi Hasil Easy Fit Data Waktu Pelayanan

\begin{tabular}{lccccl}
\hline \multicolumn{1}{c}{ Shelter } & D $_{\text {hitung }}$ & $\mathbf{D}_{\text {tabel }}$ & $\boldsymbol{p}$-value & Keputusan & \multicolumn{1}{c}{ Kesimpulan } \\
\hline Victoria Residence & 0,03971 & 0,06416 & 0,46808 & $\mathrm{H}_{0}$ diterima & $\begin{array}{l}\text { Berdistribusi Generalized } \\
\text { Extreme Value }\end{array}$ \\
Marina & 0,08163 & 0,06359 & 0,00432 & $\mathrm{H}_{0}$ ditolak & $\begin{array}{l}\text { Tidak berdistribusi } \\
\text { Generalized Pareto }\end{array}$ \\
Bandara Ahmad Yani & 0,06264 & 0,11477 & 0,61917 & $\mathrm{H}_{0}$ diterima & $\begin{array}{l}\text { Berdistribusi Generalized } \\
\text { Extreme Value }\end{array}$ \\
\hline
\end{tabular}

Jadi, pada taraf signifikansi 5\% didapatkan hasil bahwa data pelayanan BRT pada Shelter Victoria Residence dan Shelter Bandara Ahmad Yani berdistribusi Generalized 
Extreme Value. Sedangkan Shelter Marina berdistribusi General karena nilai $\mathrm{p}$-value $<\alpha=5 \%$, sehingga menolak $\mathrm{H}_{0}$ (Data berdistribusi Generalized Pareto).

Berdasarkan uji kecocokan distribusi tersebut, dapat disimpulkan bahwa:

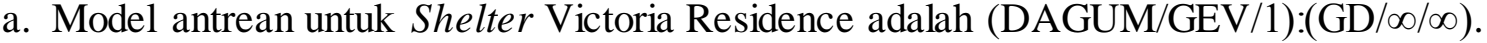

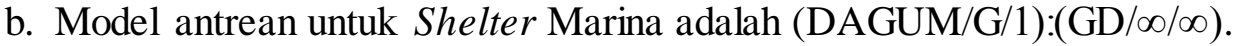

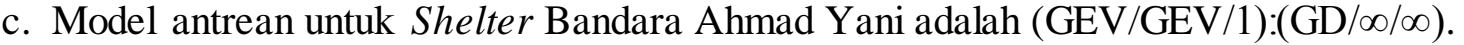

\subsection{Analisis Ukuran Kinerja Sis tem Antrean Shelter Pemberangkatan Koridor V}

Setelah dilakukan analisis steady-state dan menentukan model antrean yang sesuai, langkah selanjutnya yaitu melakukan analisis kinerja sistem antrean dengan menggunakan program GUI-R akan diperoleh tabel hasil akhir antrean sebagai berikut:

Tabel 6. Ukuran Kinerja Sistem

\begin{tabular}{lcccccc}
\hline \multicolumn{1}{c}{ Shelter } & $\boldsymbol{P r}$ & $\boldsymbol{P o}$ & $\boldsymbol{L}_{\boldsymbol{q}}$ & $\boldsymbol{L}_{\boldsymbol{s}}$ & $\boldsymbol{W}_{\boldsymbol{s}}$ & $\boldsymbol{W}_{\boldsymbol{q}}$ \\
\hline Victoria Residence & 0,67710 & 0,32889 & 0,03741 & 0,71452 & 0,13583 & 0,00711 \\
Marina & 0,42971 & 0,57029 & 0,00733 & 0,43704 & 0,08545 & 0,00143 \\
Bandara Ahmad Yani & 0,81485 & 0,18515 & 0,2337 & 1,0486 & 0,2935 & 0,0654 \\
\hline
\end{tabular}

Berdasarkan Tabel 6 dapat diketahui ukuran kinerja sistem antrean shelter pemberangkatan koridor V BRT Trans Semarang adalah sebagai berikut :

1. Probabilitas busy sistem $(\operatorname{Pr})$ :

Shelter Victoria Residence $=67,71 \%$, Shelter Marina $=42,97 \%$, dan Shelter Bandara Ahmad Yani $=81,49 \%$.

Shelter Bandara Ahmad Yani memiliki probabilitas busy system (Pr) yang lebih tinggi daripada shelter yang lainnya. Hal tersebut berarti bahwa sistem antrean pada Shelter Bandara Ahmad Yani cukup sibuk, karena probabilitas tidak adanya BRT pada shelter yaitu $18,51 \%$.

2. Jumlah BRT yang diperkirakan dalam antrean $(L q)$ :

Pada interval waktu 60 menit BRT yang menunggu dalam antrean untuk mendapatkan pelayanan untuk Shelter Victoria Residence adalah $\approx 1$ BRT, Shelter Marina $\approx 1$ BRT, dan Shelter Bandara Ahmad Yani $\approx 1$ BRT.

3. Jumlah BRT yang diperkirakan dalam sistem $(L s)$ :

Pada interval waktu 60 menit BRT yang menunggu dalam sistem untuk mendapatkan pelayanan untuk Shelter Victoria Residence adalah $\approx 1$ BRT, Shelter Marina $\approx 1$ BRT, dan Shelter Bandara Ahmad Yani $\approx 2$ BRT.

4. Waktu menunggu yang diperkirakan dalam sistem $(W s)$

Rata-rata waktu yang dihabiskan oleh satu BRT dari awal memasuki antrean sampai selesai dilayani untuk Shelter Victoria Residence $=8,15$ menit $(0,13583 \times 60$ menit), Shelter Marina $=5,13$ menit $(0,08545 \times 60$ menit $)$, dan Shelter Bandara Ahmad Yani $=$ 17,61 menit $(0,29352 \times 60$ menit).

5. Waktu menunggu yang diperkirakan dalam antrean $(W q)$

Rata-rata waktu yang dihabiskan satu BRT menunggu dalam antrean sebelum mendapatkan pelayanan untuk Shelter Victoria Residence $=0,43$ menit $(0,00711 \times 60$ menit), Shelter Marina =0,09 menit $(0,00143 \times 60$ menit), dan Shelter Bandara Ahmad Yani $=3,93$ menit $(0,06543 \times 60$ menit $)$. 


\section{KESIMPULAN}

Berdasarkan hasil analisis penelitian yang telah dilakukan, dapat disimpulkan beberapa hal sebagai berikut:

1. Sistem antrean shelter pemberangkatan koridor V BRT Trans Semarang (Victoria Residence, Marina, dan Bandara Ahmad Yani) sudah stabil karena memiliki nilai utilitas kurang dari satu.

2. Model akhir untuk antrean pada shelter pemberangkatan koridor V BRT Trans Semarang dengan data waktu antar kedatangan dan waktu pelayanan untuk Shelter

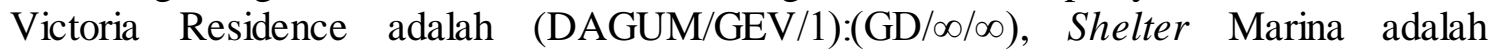

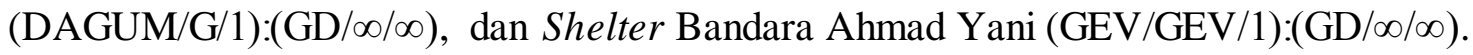

3. Berdasarkan nilai dari ukuran-ukuran kinerja sistem antrean yang diperoleh secara keseluruhan dapat disimpulkan bahwa ketiga shelter pemberangkatan koridor V BRT Trans Semarang memiliki kondisi yang sudah baik.

\section{DAFTAR PUSTAKA}

Bronson, R., dan Naadimuthu, G. 1997. Operation Research: Second Edition. New York: McGraw Hill.

Daniel, W. W. 1989. Statistik Nonparametrik (Terjemahan). Jakarta: PT. Gramedia.

Gross, D., dan Harris, C. M. 1998. Fundamental of Queueing Theory : Third Edition. New York: John Willey and Sons INC.

Kakiay, T. J. 2004. Dasar Teori Antrian untuk Kehidupan Nyata. Yogyakarta: ANDI.

Kleiber, C., dan Kotz, S. 2003. Statistical Size Distributions in Economics and Actuarial Sciences. New Jersey: Wiley-Interscience.

Kotz dan Nadarajah. 2000. Extreme Value Distributions Theory and Applications. London: Imperial College Press.

Natarajan, A. M., dan Tamilarasi, A. 2005. Probability Random Process and Queueing Theory. New Delhi: New Age International.

Siagian, P. 1987. Penelitian Operasional: Teori dan Praktek. Jakarta: Universitas Indonesia Press.

Subagyo, Asri, M., dan Handoko, T. H. 1992. Dasar-Dasar Operation Research. Yogyakarta: BPFE.

Supranto, J. 2006. Riset Operasi Untuk Pengambilan Keputusan. Jakarta: Penerbit Universitas Indonesia.

Taha, H. A. 2017. Operations Research An Introduction:Tenth Edition. Harlow: Pearson Education.

Trans Semarang. 2018. Profil BRT Semarang. transsemarang.semarangkota.go.id. Diakses: 22 Desember 2019. 